\title{
ERK Inhibitor CC-90003
}

National Cancer Institute

\section{Source}

National Cancer Institute. ERK Inhibitor CC-90003. NCI Thesaurus. Code C119747.

An orally available inhibitor of extracellular signal-regulated kinase (ERK), with potential antineoplastic activity. Upon oral administration, CC-90003 inhibits ERK activity, and prevents the activation of ERK-mediated signal transduction pathways. This results in the inhibition of ERK-dependent tumor cell proliferation and survival. The mitogen-activated protein kinase (MAPK)/ERK pathway is often upregulated in a variety of tumor cell types and plays a key role in tumor cell proliferation, differentiation and survival. 